\section{Crisis at London Zoo}

SIR - London Zoo is in crisis. It has operated at a loss for a decade. The zoo's executives, the council of the Zoological Society of London (ZSL) who put them in place, and the society's fellows can all agree on that. Closure has been threatened, and used to menace the public (with some success) and the government (latterly unsuccessfully) into giving money to "Save Our Zoo". At the society's recent annual general meeting and in two subsequent meetings arranged for management to air its plans, many fellows have been confirmed in their belief that the crisis is more deeply rooted than in finances alone. There have been numerous failures to manage well and to negotiate for funds appropriately, but in a sense these are symptomatic, not causative. Rather, the zoo has drifted for years - and has now drifted near to a decision to close without either defining for itself a role which is self-evidently valuable, or having any guiding philosophy. It is failing precisely because it is seen to have neither. We fear that if the zoo closes, the Institute of Zoology, and perhaps the society, will follow shortly afterwards.

We think structural change in management is needed. The present executive has hawked grand plans for theme park

\section{Continental drift}

SIR - The hypothesis of continental drift and its subsequent generalization to plate tectonics has revolutionized geological thinking. Although Wegener championed the cause of continental drift, he was not the first to suggest that the continents moved apart. Hallam ${ }^{1}$ points out that we must distinguish between the case where only similarities between continental coastlines are noted and the case where lateral motion is also suggested. Antonio Snider-Pelegrini (referenced by Hallam) did suggest continental break-up and drifting in 1858 in $L a$ Création et ses mystères devoilés but I recently discovered a publication that predates this work by 20 years.

Thomas Dick ${ }^{2}$ of Broughty Ferry, Scotland, in a book entitled Celestial Scenery; or The Wonders of the Planetary System Displayed; Illustrating the Perfections of the Deity and a Plurality of Worlds and, according to Houzeau originally published in $1838^{3}$, wrote:

There is a striking correspondence between two sides of the two continents to which we have adverted, the prominent parts of the one corresponding to the indentings of the other. If we look at a terrestrial globe or map of the world, we shall perceive that the projection of the developments since 1988. A low-cost attempt to adopt straightforward conservation ideals such as those of the World Conservation Union (IUCN), backed by serious education and research, does not seem to have occurred to them. We contend that this worthwhile purpose is likely to ensure the future of London Zoo through visitors and sponsors just as it currently secures more enlightened zoos worldwide. Some seven directors run the business, yet there is no full-time Director of London Zoo to embrace this kind of thinking.

With the aim of reorganizing management to the ultimate benefit of the zoo, we and a hundred or so other fellows are "requisitioning" a special general meeting of the society to debate resolutions to this end. (The terminology, and our very restricted opportunities for action, derive from our early nineteenth century charter.) Quaintly, but frustratingly, no list of members' addresses is allowed to us. In consequence we shall be grateful if ZSL fellows and others wanting more information would contact us at the address below.

CHRISTINE HAWKEY, RUTH SOBER, SIMON BEARDER, Stephen CobB, COlin Tudge, GrahaM MitCHELL

Ad Hoc Group of ZSL Fellows,

13 St Giles, Oxford OX1 3JS, UK

eastern coast of Africa nearly corresponds with the opening between North and South America, opposite to the Gulf of Mexico; that the projection in South America, about Cape St. Roque and St. Salvador, nearly corresponds with the opening in the Gulf of Guinea; so that, if we could conceive the two continents being brought into contact, the openings to which I have referred would be nearly filled up, so as to form one compact continent .... A consideration of these circumstances renders it not altogether improbable that these continents were originally conjoined, and that at some former physical revolution or catastrophe, they may have been rent asunder by some tremendous power, when the waters of the ocean rushed in between them, and left them separated as we now behold them.

Unless an earlier publication by someone else is found. Dick deserves credit for being the first specifically to mention the possibility of continents' moving apart.

\section{Geological Survey of Canada}

ALAN GOODACRE

\section{Observatory Crescent,}

\section{Ottawa, Ontario}

\section{Canada K1A OY3}

1. Hallam. A. A Revolution in the Earth Sciences, 127 (Clarendon, Oxford, 1973).

2. Dick, T. Celestial Scenery, 181 (reprinted by W. P. Fetridge and Co., New York

3. Houzeau, J. C. \& Lancaster, A. General Bibliography of Astronomy to the Year 1880, Vol. II, 2225 (reprinted by Holland, London, 1964).
Worrying trends

SIR - It would be difficult to fault much of Evelyn B. Sherr's defence of prophets of catastrophic outcomes of present trends of human development (Nature 352, 752; 1991). I wonder, however, if a continuation of Sherr's own arguments might not give a more optimistic picture.

I can readily accept that no plausible extrapolation of present trends would give to the 1988 world population of 5,000 million, still less the projected $A D$ 2100 population of 15,000 million, the $\$ 11,275$ gross national product (GNP) per head of the more favoured developed nations. If, however, such an outcome is beyond the resources of the planet, it will not happen, so we need not get too worried about it. Nor is it at all obvious that those nations that do not acquire their electric toothbrushes and bottled water will be missing all that much.

Moreover, as far as the developed industrial countries are concerned, there is no evidence to suppose that their continued development will be restricted by the resources of the planet in the foreseeable future. Far from running out of soil, they are forced to take land out of production to avoid unmanageable food surpluses. At some time, they will exhaust fossil fuel supplies, but when they are faced with an unavoidable choice they will resort to nuclear energy to whatever extent is required to stop the lights going out. Nor does population growth appear much of a threat in more developed countries.

One is then left with Sherr's fear about the consequences of unchecked population growth in less developed countries. Here Sherr would not have an easy task to show that human communities have historically tended to grow beyond the resources required to sustain them. Moreover, if they did, there would be little point in the developed countries providing resources for them, since further population growth would presumably exhaust these as well.

Perhaps, if left to themselves, the pre-industrial countries will solve their own problems. The industrial countries should provide neither weapons to facilitate their genocidal civil wars nor the promise of long-term aid that would lead them to suppose they have no need to worry about their own population pressures.

If this appears uncharitable, it is surely less so than a policy for developed countries that deliberately sustains population growth in developing countries to a point where the problem is beyond all remedy.

73 Cambridge Road, ALFRED ROUT

Middlesbrough,

Cleveland TS5 5NL, UK 